\title{
Molecular typing of Leishmania (Leishmania) amazonensis and species of the subgenus Viannia associated with cutaneous and mucosal leishmaniasis in Colombia: A concordance study
}

\author{
Clemencia Ovalle-Bracho, Carolina Camargo, Yira Díaz-Toro, Marcela Parra-Muñoz \\ Centro Dermatológico Federico Lleras Acosta, E.S.E., Bogotá, D.C., Colombia
}

\begin{abstract}
Introduction: Multilocus enzyme electrophoresis (MLEE) is the reference standard for the characterization of Leishmania species. The test is restricted to specialized laboratories due to its technical complexity, cost, and time required to obtain results. Polymerase chain reaction-restriction fragment length polymorphism (PCR-RFLP) is used to identify Leishmania species.

Objective: To establish the concordance between the two tests as identifying methods for circulating species in Colombia.

Materials and methods: A total of 96 isolates from patients with cutaneous or mucosal leishmaniasis were selected and identified by MLEE and PCR-RFLP with miniexon and hsp70 as the molecular targets, which were used sequentially. Restriction enzymes Haelll and $\mathrm{Bccl}$ were similarly applied. Cohen's kappa coefficient and the $95 \%$ confidence interval $(\mathrm{Cl})$ were calculated.

Results: The kappa coefficient and the $95 \% \mathrm{Cl}$ between MLEE and PCR-RFLP displayed "very good" concordance with a coefficient of 0.98 (Cl95\%: 0.98 to 1.00). The identified species were Leishmania Viannia braziliensis, Leishmania Viannia panamensis, Leishmania Viannia guyanensis and Leishmania Leishmania amazonensis. A total of 80 of the 96 isolates were sequenced and the results obtained by PCR-RFLP were confirmed.

Conclusion: Due to the concordance obtained between tests results with the amplification of the genes miniexon and hsp70, PCR-RFLP is proposed as an alternative for identifying circulating Leishmania species in Colombia.
\end{abstract}

Key words: Leishmania; leishmaniasis; molecular typing; isoenzymes; polymerase chain reaction; polymorphism, restriction fragment length.

doi: https://doi.org/10.7705/biomedica.v38i0.3632

Tipificación molecular de Leishmania (Leishmania) amazonensis y especies del subgénero Viannia asociadas a la leishmaniasis cutánea y la mucosa en Colombia: un estudio de concordancia

Introducción. La electroforesis de enzimas multilocus (Multilocus Enzyme Electrophoresis, MLEE) es el estándar de referencia para la tipificación de las especies de Leishmania. La prueba está restringida a laboratorios especializados por su complejidad técnica, sus costos y el tiempo necesario para obtener resultados. La PCR-RFLP (Polymerase Chain Reaction-Restriction Fragment Length Polymorphism) se utiliza para tipificar especies de Leishmania.

Objetivo. Establecer la concordancia entre las dos pruebas como métodos de tipificación de las especies circulantes en Colombia.

Materiales y métodos. Se seleccionaron 96 aislamientos de pacientes con leishmaniasis cutánea o mucocutánea y se tipificaron mediante MLEE y PCR-RFLP con los blancos moleculares miniexon y hsp70 usados en serie. Las enzimas de restricción aplicadas fueron la Haelll y la Bccl, respectivamente. Se calculó el coeficiente kappa y un intervalo de confianza (IC) de $95 \%$.

Resultados. Se determinó que la concordancia fue "muy buena" al obtener un coeficiente de 0,98 (IC ${ }_{95 \%}$ : 0,98-1,00). Las especies identificadas fueron: Leishmania Viannia braziliensis, $L$. (V.) panamensis, $L$. $(V$.) guyanensis y $L$. $(L$,$) amazonensis. De los 96$ aislamientos, 80 se enviaron a secuenciación y se confirmaron los resultados obtenidos mediante PCR-RFLP.

Conclusión. Dada la concordancia obtenida con la PCR-RFLP amplificando los genes miniexon y hsp70, se propone esta prueba como alternativa para la tipificación de especies de Leishmania circulantes en Colombia.

Palabras clave: Leishmania; leishmaniasis; tipificación molecular; isoenzimas; reacción en cadena de la polimerasa; polimorfismo de longitud del fragmento de restricción.

doi: https://doi.org/10.7705/biomedica.v38i0.3632

Author's contributions:

Clemencia Ovalle-Bracho: conception and design of the study and acquisition of the data

Carolina Camargo and Yira Díaz-Toro: development of the experimental aspects

All authors participated in the analysis and interpretation of the data and in the writing of the manuscript. 
Leishmaniasis is a group of endemic diseases in 98 countries, affecting approximately 12 million people, with approximately 350 million more at risk. These diseases are produced by a protozoan of the Leishmania genus with clinical manifestations in the skin, mucous membranes, and organs (1). The presentation of the disease, its evolution, and its response to treatment in the host vary according to the infective species. Therefore, identification of the diseases is relevant when determining the prognosis of the disease and when making an effective treatment choice. Species identification also allows for an understanding of the epidemiological behavior of the disease and contributes to the formulation of the control and prevention strategies appropriate to each region (2-5).

Currently, multilocus enzyme electrophoresis (MLEE) is considered the reference standard for the identification of Leishmania species due to its widespread use and ability to discriminate species in both the New and Old World (6-8). This methodology allows the characterization of the microorganisms by the electrophoretic mobility of a wide range of intracellular enzymes $(9,10)$. Worldwide, nine reference centers provide species identification by MLEE, and only three of them are in the Americas (1). This, added to the complexity of the technique, limits the frequent application of this methodology to characterize Leishmania species in Colombia and the world (10-12).

Polymerase chain reaction (PCR) followed by an analysis of restriction fragment length polymorphism (RFLP) offers an alternative for identifying Leishmania species by analyzing the characteristic patterns of the different species obtained using restriction enzymes on amplified products of the genetic material of interest. This methodology has been expanded in the last two decades due to its speed in obtaining results, its ability to discriminate between species, and to adapt it to somewhat complex conditions regarding available technical resources, as well as the possibility of identifying Leishmania species directly from clinical samples $(4,11,13,14)$.

\footnotetext{
Corresponding author:

Clemencia Ovalle-Bracho, Grupo Dermatología Tropical, Centro Dermatológico Federico Lleras Acosta, Avenida 1a Nº 13A-61, Bogotá, D.C., Colombia

Telephone: (571) 242 8160, extension 115

clemovalle@gmail.com
}

Received: 04/10/16; accepted: 18/05/17
For identifying Leishmania species via PCRRFLP, different molecular targets have been used. Some of the most frequently used have been kinetoplast DNA (kDNA) (15-18), the GP63 gene (4), the $\beta$-tubulin gene (19), ITS rDNA $(18,20)$, the miniexon gene (21-24), and the gene that encodes heat shock protein 70 (hsp70) $(2,25)$.

Previous studies from our group have focused on identifying circulating species of Leishmania in Colombia by using MLEE, monoclonal antibodies and PCR with kDNA, ITS rDNA, miniexon and hsp70 as targets, with the last two being those that allow differentiation of all subgenus Leishmania and Viannia species circulating in Colombia (18,26-29).

Amplification of the miniexon gene permits to identify the species $L$. (L.) amazonensis, $L$. (L.) mexicana, and $L$. ( $L$.) infantum by differences in amplified product size $(22,23)$. When amplification is followed by restriction using the Haelll enzyme, it is possible to identify $L$. (V.) braziliensis but not the complex $L$. (V.) panamensis/L. (V.) guyanensis $(22-24,30)$. The hsp70 gene amplification followed by RFLP with the Bccl enzyme allows to differentiate between $L$. (V.) panamensis and L. (V.) guyanensis $(25,31,32)$.

The aim of this study was to establish the concordance between PCR-RFLP using miniexon and hsp70 as molecular targets and the reference standard MLEE for the identification of circulating Leishmania species in Colombia.

\section{Materials and methods}

\section{Type of design}

We conducted a concordance study that used MLEE and PCR-RFLP for the identification of the Leishmania species circulating in Colombia.

\section{Study population}

Isolates came from patients diagnosed with cutaneous, diffuse and mucosal leishmaniasis who visited the Centro Dermatológico Federico Lleras Acosta E.S.E. between 1999 and 2011.

\section{Sample}

We included 96 samples out of the 800 available at the biological bank. The inclusion criteria was strains previously identified under the indirect fluorescent antibody test and classified like null phenotype.

\section{Reference strains}

The reference strains included $L$. (V.) braziliensis (MHOM/BR/75/M2903), L. (V.) panamensis (MHOM/ PA/71/LS94), L. (V.) guyanensis (MHOM/BR/75/ 
M4147), L. (L.) amazonensis (IFLA/BR/67/PH8), and $L$. (L.) mexicana (MNCY/BZ/62/M379). The electrophoretic and restricted patterns of the reference strains were used to determine the species of the isolates.

\section{Parasite culture}

Parasites were cultured in Senekjie's medium and incubated at $26^{\circ} \mathrm{C}$ until we obtained a primary culture. Subsequently, a mass culture was performed using Schneider's medium supplemented with $10 \%$ fetal bovine serum (33).

\section{Species identification}

Identification by MLEE and PCR-RFLP were performed from the same isolated sample. Samples were processed by different professionals for each of the tests. Isoenzyme identification was performed in a reference center of the Pan American Health Organization (PAHO).

\section{Identification by MLEE}

The preparation of the extract for analysis and the isoenzyme was performed according to the methods described by Saravia, et al. $(34,35)$. Isoenzyme electrophoresis of the clinical isolates and reference strains was performed on a cellulose support according to the method described by Godfrey, et al. (36).

\section{DNA extraction}

The cetyltrimethylammonium bromide method was performed as described by Wagner, et al., in 1987 and used for both the reference strains and the clinical isolates (37).

\section{Miniexon gene PCR}

For gene amplification we used the primers reported by Marfurt, et al. $(22,23)$. Each PCR reaction contained $20 \mathrm{mM}$ Tris- $\mathrm{HCl} \mathrm{pH} 8.4 ; 50 \mathrm{mMKCl} ; 1$ mM MgCl2; $200 \mu \mathrm{MdATP}$, dCTP, dTTP and dGTP; $0.5 \mu \mathrm{M}$ of each primer (Fme 5'-TAT TGG TATGCG AAA CTT CCG-3' and Rme 5'-ACA GAA ACT GAT ACT TAT ATA GCG-3') and DMSO 6\%, $2 \mu \mathrm{l}$ of DNA at $10 \mathrm{ng} / \mu \mathrm{l}$ and 0.05 units of Taq Polymerase Platinum (Invitrogen, São Paulo, Brasil) at a final volume of $50 \mu \mathrm{l}$.

Amplification was performed with the following conditions: An initial DNA denaturation at $95^{\circ} \mathrm{C}$ for 8 minutes; 40 amplification cycles of $95^{\circ} \mathrm{C}$ for $20 \mathrm{~s}, 55^{\circ} \mathrm{C}$ for $30 \mathrm{~s}$ and $72^{\circ} \mathrm{C}$ for $30 \mathrm{~s}$; and a final extension cycle at $72^{\circ} \mathrm{C}$ for 5 minutes.

\section{hsp70 gene PCR}

Amplification was performed following the protocol proposed by García, et al. (25). Each PCR reaction contained $20 \mathrm{mMTris}-\mathrm{HCl} \mathrm{pH} \mathrm{8.4;50} \mathrm{mMKCl;} 2 \mathrm{mM}$ $\mathrm{MgCl} 2 ; 200 \mu \mathrm{MdATP}$, dCTP, dTTP and dGTP;0.4 $\mu \mathrm{M}$ of each primer (hsp70 sen 5'-GAC GGT GCC TGC CTA CTT CAA-3' and hsp70 ant 5'-CCG CCC ATG CTC TGG TAC ATC-3'); 10\% DMSO; $2 \mu \mathrm{l}$ of DNA at $10 \mathrm{ng} / \mu \mathrm{l}$ and 0.05 units of Taq Polymerase Platinum (Invitrogen, São Paulo, Brazil) at a final volume of $50 \mu \mathrm{l}$.

Amplification was performed using the following protocol: An initial DNA denaturation at $94^{\circ} \mathrm{C}$ for 5 minutes; 33 amplification cycles at $94^{\circ} \mathrm{C}$ for 1 minute, $64^{\circ} \mathrm{C}$ for 1 minute and $72^{\circ} \mathrm{C}$ for 3 minutes; and a final extension cycle at $72^{\circ} \mathrm{C}$ for 10 minutes.

\section{Visualization of the miniexon and hsp70 PCR products}

Amplicons of the miniexon and hsp70 genes were analyzed by electrophoresis in $1 \%$ and $2 \%$ agarose gels, respectively. For the identification of species through PCR-RFLP, the molecular weights of the amplicons from the miniexon gene must be considered: 308 bp for $L$. (L.) mexicana, 283 bp for $L$. (L.) amazonensis, and 418 bp for the $L$. ( $L$.) chagasi control, and between 255 and 227 bp for the Viannia subgenus $(22,23)$. The hsp70 gene presents a 1422-bp band for the Viannia subgenus (38).

\section{Restriction fragment length polymorphism (RFLP)}

Samples showing an amplification profile of the miniexon gene compatible with the Viannia subgenus were subjected to restriction with the Haelll enzyme (Invitrogen, São Paulo, Brazil).

The hsp70 gene of the samples that were identified as $L$. (V.) panamensis/L. (V.) guyanensis through the miniexon gene PCR-RFLP was also amplified and digested with the $\mathrm{Bccl}$ enzyme (New England Biolabs, Ipswich, England).

Amplicons of the miniexon and hsp70 genes were purified using QIA quick PCR Purification kits (Qiagen, Düsseldorf, Germany). A total of $12.5 \mu \mathrm{l}$ of purified PCR product was used for the digestion, with the addition of $1.4 \mu \mathrm{l}$ of reaction buffer and 0.5 $\mu \mathrm{l}$ of restriction enzymes Haelll $(10 \mathrm{U} / \mu \mathrm{l})$ and $\mathrm{Bccl}$ $(10 \mathrm{U} / \mu \mathrm{l})$; the mix was incubated at $37^{\circ} \mathrm{C}$ for 120 minutes and at 45 volts.

Restriction products were analyzed by electrophoresis using high-resolution $2.5 \%$ agarose gels (Sigma-Aldrich, St. Louis, Missouri, USA) at $2.5 \mathrm{~V} /$ $\mathrm{cm}$ for 1.5 hours; a 100-bp molecular-weight marker was used (Bioline, London, England). 
The samples that presented a restriction pattern of two bands of 108 and 118 bp with the Haelll enzyme were identified as $L$. $(V$.) braziliensis. Amplicons that did not show a restriction pattern were identified as L. (V.) panamensis/L. (V.) guyanensis.

The restriction products obtained through the Bccl enzyme in the reference strains $L$. $(V)$ panamensis (MHOM/PA/71/LS94) and L. (V) guyanensis (MHOM/ BR/75/M4147) showed the following patterns: Two bands of 428 and $890 \mathrm{bp}$ and three bands of approximately 346, 428 and 544 bp. Species of clinical isolates were determined based on the restriction patterns obtained with reference strains.

\section{Sequencing}

We selected 80 isolates by simple random sampling and sequenced them to confirm the species identified by PCR and PCR-RFLP, including the samples identified as $L$. (V.) panamensis, L. (V.) braziliensis, $L$. (V.) guyanensis, and L. (V.) amazonensis. For sequencing we used a BigDye Terminator, v3.1, Cycle Sequencing Kit (Applied Biosystems, Foster City, CA, USA) and an Applied Biosystems 3730xI DNA Analyzer system (Applied Biosystems, Foster City, CA, USA). For the analysis we used the software Geneious Pro 5.5.6 (Biomatters Ltda, Auckland, New Zealand) to align the sequences obtained with the sequences available at NCBI of the particular genes of the species of interest.

\section{Statistical analysis}

The results of the MLEE and PCR-RFLP of the species identified were recorded in an Excel database (Microsoft Office XP). Cohen's kappa coefficient and the $95 \% \mathrm{Cl}$ were calculated using the software Stata ${ }^{\circledR}$, version 13 (Stata Corp LP, College Station, Texas, USA) to determine the concordance between the MLEE and PCR-RFLP results.

\section{Ethical considerations}

This study was classified as safe and approved by Centro Dermatológico Federico Lleras Acosta E.S.E. Ethical Committee for the use of cryopreserved samples according to the ethical guidelines established by the Ethics Committee in Research, which are based on the Declaration of Helsinki and current Colombian regulations.

\section{Results}

The identification of the species for the isolates was performed according to the results obtained by PCR, PCR-RFLP and MLEE: L. (V.) braziliensis: $63.5 \%, L$. (V.) panamensis: $21.9 \%$, L. (V.) guyanensis: $5.2 \%$ and $L$. (L.) amazonensis: 9.4\%. Sequencing confirmed the results obtained by PCR and PCRRFLP. Figures 1 and 2A show PCR-miniexon gene and PCR-hsp70 gen amplification products from different Leishmania reference strains and clinical samples, respectively. The figure $2 \mathrm{~B}$ shows restriction endonuclease DNA fragment patterns from amplicons of the PCR-hsp70 gene using Bccl enzyme. Table 1 shows the identification results obtained by MLEE, miniexon gene PCR-RFLP, and hsp70 gene PCR-RFLP, and table 2 shows the results obtained by sequencing.

The concordance between the results of Leishmania species identification by PCR-RFLP and MLEE was "very good" according to the scale of Landis, et al. (39), for obtaining a kappa of 0.98 (C195\%: 0.98-1).

Among the 96 samples analyzed by both molecular tests (miniexon gene PCR-RFLP and hsp70 gene PCR-RFLP) and by MLEE, only one discordant result was observed. One of the isolates was identified through molecular tests as $L$. (V.) braziliensis but as $L$. (V.) panamensis by MLEE.

We obtained 96 isolates from patients whose ages ranged between 1.4 and 73 years and who had been diagnosed with cutaneous, diffuse cutaneous or mucosal leishmaniasis.

The patients came from 51 municipalities endemic for leishmaniasis in 15 different departments: Antioquia $(n=1)$, Boyacá $(n=4)$, Caldas $(n=4)$, Caquetá $(n=15)$, Casanare $(n=2)$, Cundinamarca $(n=24)$, Guainía $(n=1)$, Guaviare $(n=6)$, Meta $(n=21)$, Nariño $(n=1)$, Risaralda $(n=1)$, Santander $(n=4)$, Tolima $(n=6)$, Valle del Cauca $(n=2)$, and Vichada $(n=4)$ (figure 3).

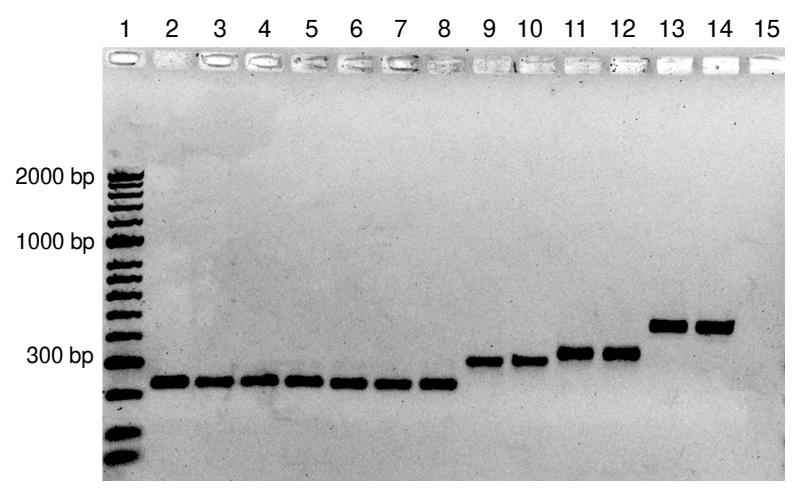

Figure 1. A. Line 1, molecular weight marker; Line 2, L. (V.) braziliensis reference strain DNA; Line $3, L$. (V.) panamensis reference strain; Line 4, L. (V.) guyanensis reference strain; Lines 5-8, DNA from clinical samples of leishmaniasis cases typed as Leishmania Viannia subgenus; Lines 9-10 L. (L.) amazonensis reference strain; Lines $11-12, L$. (L.) mexicana reference strain; Lines 13-14, L. (L.) infantum; Line 15, negative control 

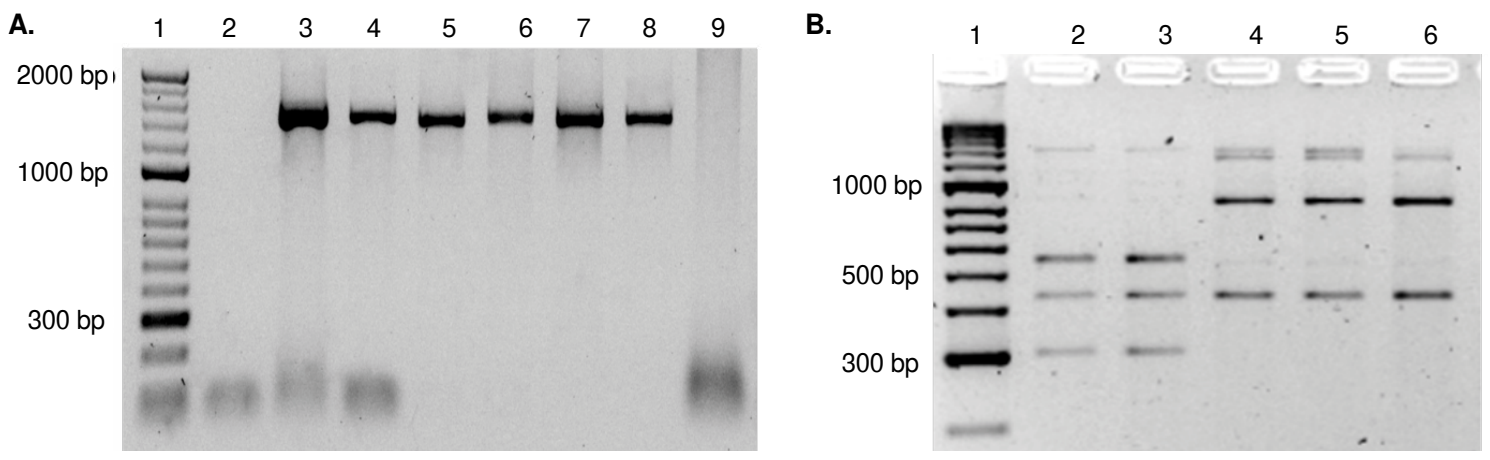

Figure 2. A. Line 1, molecular weight marker; Line 2, negative control; Line 3 L. (V.) panamensis reference strain DNA; Line 4, L. (V.) guyanensis reference strain DNA; Lines 5-8, DNA from clinical samples of leishmaniasis cases; Line 9, clinical sample from patient with suggested diagnosis of mucosal leishmaniasis and rhinoscleroma confirmed diagnosis. B. Line 1, molecular weight marker; Line 2, L. (V.) guyanensis reference strain; Line 3, clinical sample typed as $L$. (V.) guyanensis; Line 4, L. ( $V$.) panamensis reference strain; Lines 5-6, clinical samples typed as $L$. (V.) panamensis

Table 1. Typing results of 96 isolates of Leishmania spp. by MLEE and PCR-RFLP methods

\begin{tabular}{lrcc}
\hline & MLEE & $\begin{array}{c}\text { PCR-RFLP } \\
\text { miniexon gene }\end{array}$ & $\begin{array}{c}\text { PCR-RFLP } \\
\text { hsp70 gene }\end{array}$ \\
\hline L. $(V$.$) braziliensis$ & 60 & 61 & - \\
L. $(V$.$) panamensis$ & 22 & - & 21 \\
L. $(V$.$) guyanensis$ & 5 & - & 5 \\
L. $(V$.$) panamensis/L.$ & - & 26 & - \\
(V.) guyanensis & & & - \\
L. (L.) amazonensis & 9 & 9 & 26 \\
Total & 96 & 96 & \\
\hline
\end{tabular}

I: Method applied only to 26 samples classified as $L$. (V.) panamensis/L. $(V$.) guyanensis by PCR-RFLP with the miniexon gene

Table 2. Typing results of 80 isolates of Leishmania spp. by MLEE and PCR-RFLP miniexon/hsp70 methods evaluated by sequencing

\begin{tabular}{lccc}
\hline & Sequencing & MLEE & $\begin{array}{c}\text { PCR-RFLP } \\
\text { miniexon/hsp70 }\end{array}$ \\
\hline L. (V.) braziliensis & 47 & 46 & 47 \\
L. (V.) panamensis & 20 & 21 & 20 \\
L. (V.) guyanensis & 4 & 4 & 4 \\
L. (L.) amazonensis & 9 & 9 & 9 \\
Total & 80 & 80 & 80 \\
\hline
\end{tabular}

\section{Discussion}

According to the criteria of Landis, et al. (39), this study achieved a "very good" concordance between MLEE and PCR-RFLP of the miniexon and hsp70 genes for characterizing circulating Leishmania species in Colombia from clinical isolates. These results indicate that those obtained using PCRRFLP for the species under study are equivalent to the results obtained using MLEE, which is considered the reference standard $(1,6)$. The tests were applied on samples from the five geographical regions of the country, suggesting that it is possible to identify species despite the intraspecies variability associated with geographical distribution.

MLEE is a useful technique for characterizing species, as it permits the analysis of genetic variability between and among species, as well as their taxonomies and phylogenies $(40,41)$. However, this methodology does not permit the direct identification of clinical specimens, the culture is required and it has low sensibility for samples from patients with mucosal and chronic cutaneous leishmaniasis, which prevents obtaining large amounts of parasites. Besides, MLEE is technically demanding and requires prolonged times for obtaining results $(10-12,41)$. An alternative to discriminate between Leishmania species is PCR-RFLP, a widely used test that is performed with different molecular targets to determine the ability to differentiate species (42).

The miniexon and hsp70 genes were selected to identify circulating species in Colombia as they have several advantages: The number of copies of the genes allows for good test sensitivity, and these genes have been validated on a global scale with Old and New World species.

Recently, van der Auwera, et al., concluded after the analysis of several publications that the miniexon and hsp70 genes, compared to other molecular targets, exhibit the best resolution to identify medically relevant Leishmania species (43). This claim is supported by experimental studies of the miniexon gene performed by Marfur, et al., as well as studies performed by Serin, et al., who evaluated the functionality of the miniexon gene as a phylogenetic marker of 17 species of the New 


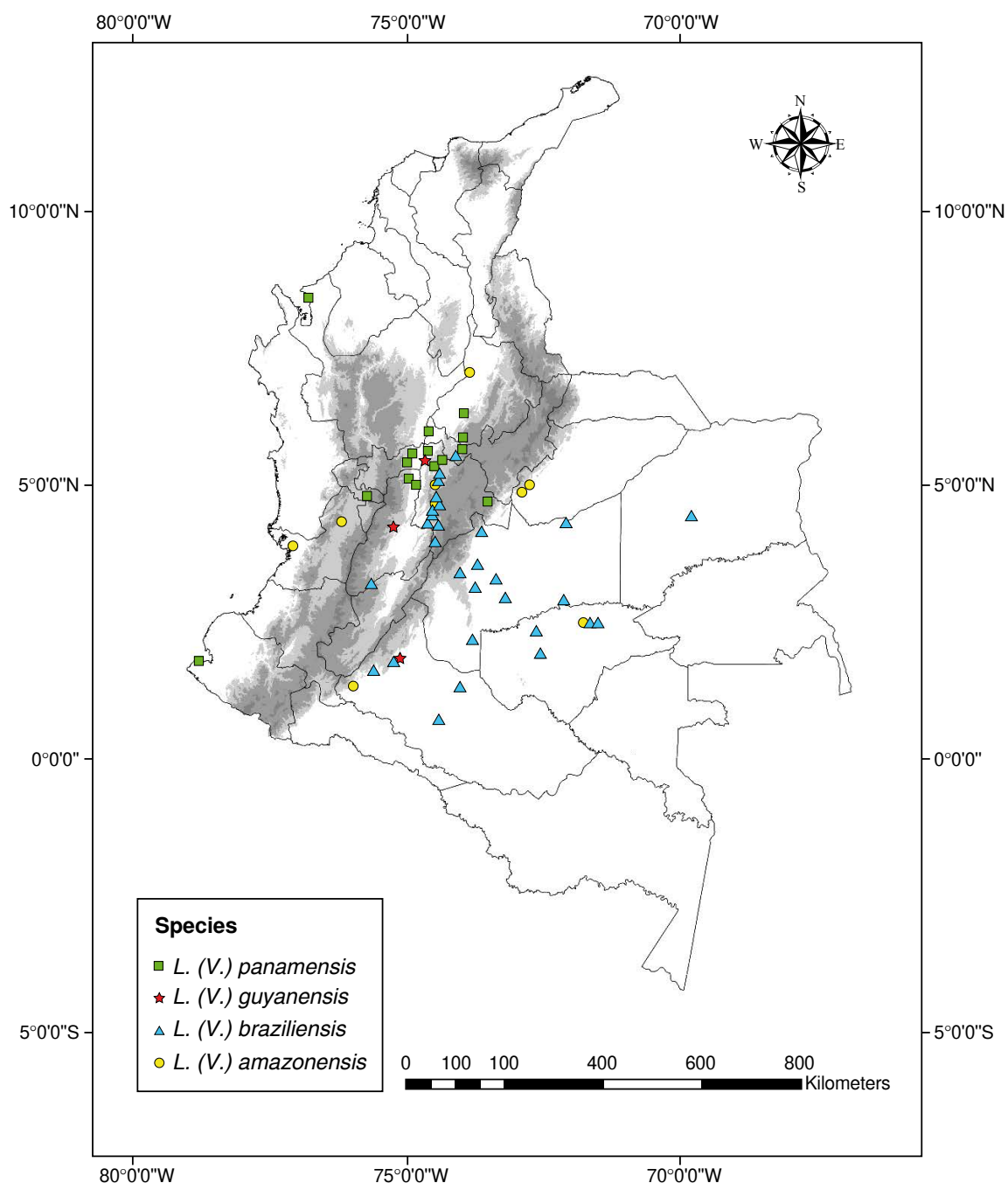

Figure 3. Distribution of Leishmania species identified by PCR-RFLP with miniexon and hsp70as molecular targets. Map done using ArcGis vr. 10.2 program; the altitude was obtained from the WorldClim database with $1 \mathrm{~km}$ resolution (http://www.worldclim.org/).

and the Old World (22-24). The hsp70 gene has been evaluated for almost all circulating species in the world, with results that demonstrate its discriminatory capacity $(28,32,44)$.

In our study, we identified $L$. (V.) braziliensis using PCR-RFLP, and L. (L.) amazonensis using only PCR based on amplicon size, results that were confirmed by sequencing. In Colombia, even though the prevalent species are associated with the Viannia subgenus, L. (L.) amazonensis recently was associated with cutaneous, diffuse cutaneous, and mucosal leishmaniasis. PCR of the miniexon gene allows the identification of $L$. (L.) amazonensis, $L$. (L.) mexicana, and $L$. (L.) chagasi only by amplicon size. This approach is very useful and less expensive than other methods that require additional tests such as RFLP or sequencing.
The hsp70 gene has also been extensively evaluated in Old and New World species. García, et al., were the first to identify its functionality to diagnose and differentiate species from the subgenera Leishmania and Viannia, complemented with techniques such as RFLP and sequencing $(29,32,38,45-48)$.

This technique has also proven to be useful in differentiating species from the $L$. guyanensis complex, which includes $L$. (V.) panamensis and $L$. $(V$.) guyanensis. These species are of great clinical and epidemiological interest in Colombia because $L$. $(V$.) guyanensis was associated with the largest epidemic of leishmaniasis in the country. This species also presents differences in the in vitro susceptibility response to drugs compared to other species of the Viannia subgenus $(49,50)$. 


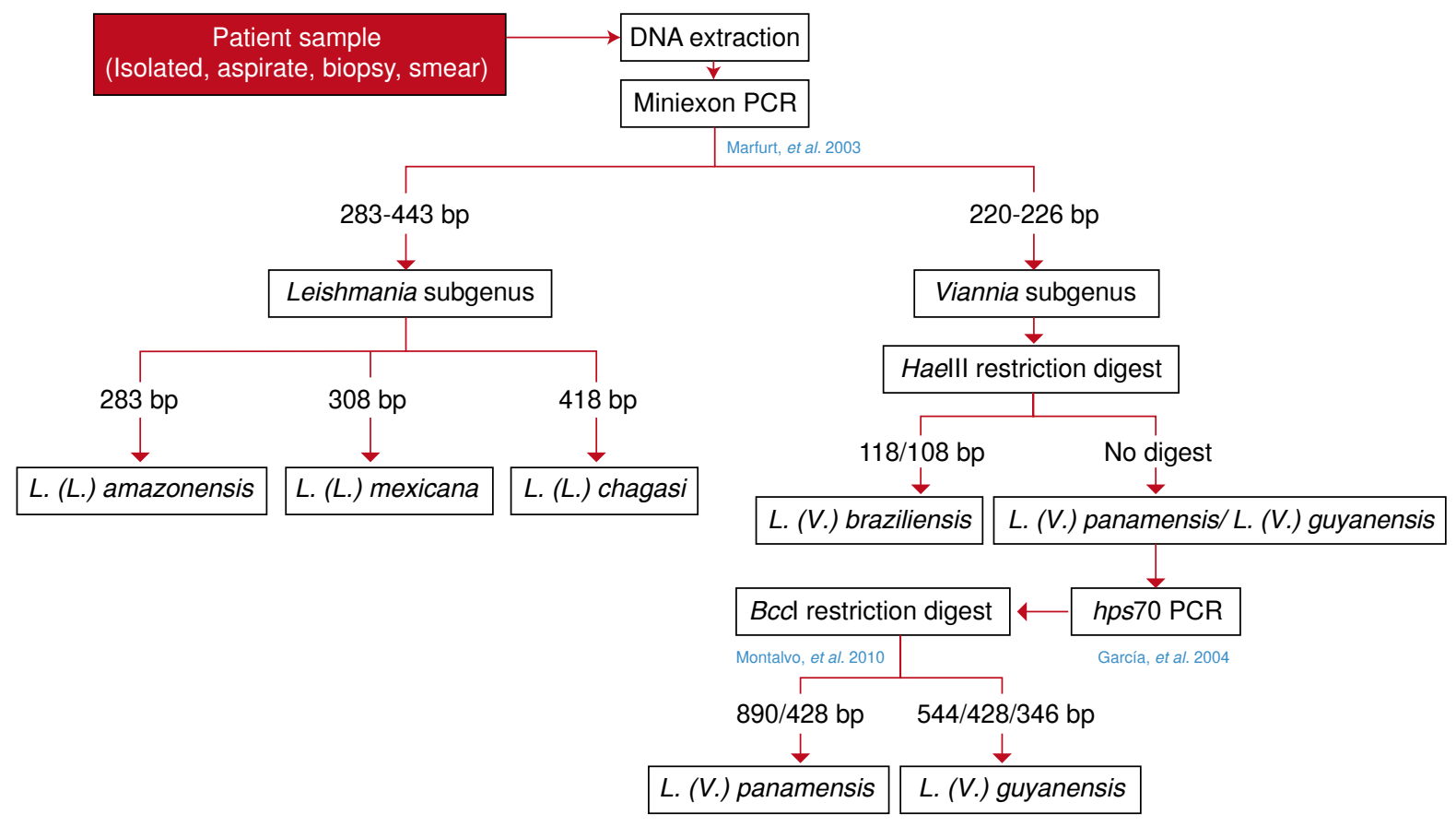

Figure 4. Identification algorithm of Leishmania species with miniexon and hsp70 as molecular targets

In our study, hsp70 gene amplification and RFLP using the enzyme Bccl were very useful, as they allowed discrimination between $L$. ( $V$.) panamensis and $L$. (V.) guyanensis. The results obtained in the concordance analysis between the two tests suggest that they are equivalent for identifying the species circulating in Colombia. Our results are consistent with those obtained by da Silva, et al., who found an overall concordance between MLEE and PCRRFLP of the hsp70 gene of the circulating species in Brazil, based on which the authors concluded that the latter method can replace MLEE in the routine identification of Leishmania species (51).

Another method recently used to identify species is the high-resolution analysis of dissociation using the hsp70 gene, which has demonstrated good agreement with PCR-RFLP and MLEE (52). Cardoso da Graça, et al., compared the molecular targets ITS, G6PD and hsp70 with MLEE, and found very good concordance between the methodologies for the identification of $L$. (L.) amazonensis, $L$. ( $L$.) infantum, L. (V.) guyanesis, L. (L.) lanzoni, L. (V.) naiffi, and $L$. ( $L$.) shawi, but discordance for the identification by MLEE of $L$. (V.) braziliensis (53), which was the only dissenting finding of the current study.

Several hypotheses have been proposed to explain the difference between the identification results of the various methodologies, including the possibility of mixed infection, variation in the patterns according to the markers used, and the similarity between species of the Viannia subgenus $(53,54)$.

The results indicate that the PCR-RFLP of the miniexon and hsp70 genes permit the identification of circulating species in the country. This test could be used in more laboratories compared to MLEE because it is technically simpler and the cost is $50 \%$ less than for MLEE. This work includes the largest number of samples reported in the country, identified by molecular tests and with a wide geographical distribution.

The test is restricted to native species, but it would be possible to expand its spectrum using other restriction enzymes to identify new circulating or imported species. Here we propose an identification algorithm for the Leishmania species that are circulating in Colombia (figure 4).

\section{Acknowledgments}

We thank the Editorial Committee of Centro Dermatológico Federico Lleras Acosta for their significant contributions to the manuscript, and Sandra Milena Montaño, for her support in the development of the species distribution map.

\section{Conflicts of interest}

The authors report no conflicts of interest. 


\section{Funding}

The study was completely developed and funded by the Centro Dermatológico Federico Lleras Acosta, E.S.E., code-project 4000-16.10

\section{References}

1. World Health Organization. Control of leishmaniases. Report of a meeting of the WHO Expert Committee on the Control of Leishmaniases. Tech Rep Ser 949. Geneva: WHO; 2010. p. 1-186.

2. Montalvo AM, Fraga J, Aylema J, Monzote L, Montano I, Dujardin JC. PCR-RFLP/hsp70 para identificar y tipificar Leishmania de la región neotropical. Rev Cubana Med Trop. 2006;58:226-34.

3. del Mar-Castro M, Cossio A, Velasco C, Osorio L. Risk factors for therapeutic failure to meglumine antimoniate and miltefosine in adults and children with cutaneous leishmaniasis in Colombia: A cohort study. PLoS Negl Trop Dis. 2017;11:1-14. https://doi.org/10.1371/journal.pntd.0005515

4. Berzunza-Cruz M, Bricaire G, Suazo NS, PérezMontfort R, Becker I. PCR for identification of species causing American cutaneous leishmaniasis. Parasitol Res. 2009;104:691-9. https://doi.org/10.1007/s00436-008-1247-2

5. Marco JD, Barroso PA, Mimori T, Locatelli FM, Tomatani A, Mora MC, et al. Polymorphism-specific PCR enhances the diagnostic performance of American tegumentary leishmaniasis and allows the rapid identification of Leishmania species from Argentina. BMC infect Dis. 2012;12:1-8. https://doi.org/10.1186/1471-2334-12-191

6. Kreutzer RD, Christensen HA. Characterization of Leishmania spp. by isozyme electrophoresis. Am J Trop Med Hyg 1980;29:199-208. https://doi.org/10.4269/ajtmh.1980.29.199

7. Cupolillo E, Grimaldi E, Momen H. Genetic diversity among Leishmania Viannia parasites. Ann Trop Med Parasitol. 1997;91:617-26. https://doi.org/10.1080/00034989760716

8. Bañuls AL, Hide M, Prugnolle F. Leishmania and the leishmaniases: A parasite genetic update and advances in taxonomy, epidemiology and pathogenicity in humans. Adv Parasitol. 2007;64:1-109. https://doi.org/10.1016/s0065308x(06)64001-3

9. Cupolillo E, Momen H, Grimaldi G. Genetic diversity in natural populations of New World Leishmania. Mem Inst Oswaldo Cruz. 1998;93:663-8. https://doi.org/10.1590/ s0074-02761998000500018

10. Stanley T, Wilson IG. Multilocus enzyme electrophoresis. Mol Biotechnol. 2003;24:203-20. https://doi.org/10.1385/1 59259-029-2:369

11. de Morais RC, da Costa CN, da Cunha S, de Albuquerque C, Mendonça LA, Pessoa-e-Silva R, et al. Real-time PCR for Leishmania species identification: Evaluation and comparison with classical techniques. Exp Parasitol. 2016; 165:43-50. https://doi.org/10.1016/j.exppara.2016.03.005

12. Zhang WW, Miranda C, Arévalo J, Ndao M, Ward B, Cuentas AL, et al. Development of a genetic assay to distinguish between Leishmania Viannia species on the basis of isoenzyme differences. Clin Infect Dis. 2006;42:801 9. https://doi.org/10.1086/500326
13. Chaara D, Bañuls AL, Haouas N, Talignani L, Lami P, Mezhoud $\mathbf{H}$, et al. Comparison of Leishmania killicki (syn. L. tropica) and Leishmania tropica population structure in Maghreb by microsatellite typing. PLoS Negl Trop Dis. 2017;9:1-13. https://doi.org/10.1371/journal.pntd.0004204

14. Buitrago R, Cupolillo E, Bastrenta B, Le Pont F, Martínez E, Barnabé C, et al. PCR-RFLP of ribosomal internal transcribed spacers highlights inter and intraspecies variation among Leishmania strains native to $\mathrm{La}$ Paz, Bolivia. Infect Genet Evol. 2011;11:557-63. https://doi. org/10.1016/j.meegid.2010.11.019

15. de Bruijn MH, Barker DC. Diagnosis of New World leishmaniasis: Specific detection of species of the Leishmania braziliensis complex by amplification of kinetoplast DNA. Acta Trop. 1992;52:45-58. https://doi.org/10.1016/0001-706x (92) $90006-j$

16. de Cássia R, Alheiros M, da Hora R, Rodríguez AL. Multiplex PCR as a tool for the diagnosis of Leishmania spp. kDNA and the gapdh housekeeping gene of mammal hosts. PloS One. 2017;12:1-12. https://doi.org/10.1371/journal. pone.0173922

17. Hamouchi A, Ejghal R, Hida M, Lemrani M. Intraspecific genetic variability in a population of Moroccan Leishmania infantum revealed by PCR-RFLP of KDNA minicircles. Acta Trop. 2017;169:142-9. https://doi.org/10.1016/j. actatropica.2017.02.016

18. Ovalle C, Porras-de Quintana L, Muvdi S, Ríos M. Polymerase chain reaction with two molecular targets in mucosal leishmaniasis diagnosis: A validation study. Mem Inst Oswaldo Cruz. 2007;102 549-54. https://doi. org/10.1590/s0074-02762007005000061

19. Mendoza-León A, Luis L, Martínez C. The $\beta$-tubulin gene region as a molecular marker to distinguish Leishmania parasites. Methods Mol Biol. 2002;179:61-83. https://doi. org/10.1385/1-59259-238-4:061

20. Cuervo P, Cupolillo E, Nehme N, Hernández V, Saravia N, Fernandes O. Leishmania (Viannia): Genetic analysis of cutaneous and mucosal strains isolated from the same patient. Exp Parasitol. 2004;108:59-66. https://doi.org/10. 1016/j.exppara.2004.07.005

21. Harris E, Kropp G, Belli A, Rodríguez B, Agabian N. Single-step multiplex PCR assay for characterization of New World Leishmania complexes. J Clin Microbiol. 1998; 36:1989-95.

22. Marfurt J, Nasereddin A, Niederwieser I, Jaffe CL, Beck HP, Felger I. Identification and differentiation of Leishmania species in clinical samples by PCR amplification of the miniexon sequence and subsequent restriction fragment length polymorphism analysis. J Clin Microbiol. 2003;41: 3147-53. https://doi.org/10.1128/jcm.41.7.3147-3153.2003

23. Marfurt J, Niederwieser I, Makia ND, Beck HP, Felger I. Diagnostic genotyping of Old and New World Leishmania species by PCR-RFLP. Diagn Microbiol Infect Dis. 2003;46: 115-24. https://doi.org/10.1016/s0732-8893(03)00040-3

24. Serin MS, Waki K, Chang KP, Aslan G, Direkel S, Otag F, et al. Consistence of miniexon polymerase chain reactionrestriction fragment length polymorphism and single-copy gene sequence analyses in discriminating Leishmania genotypes. Diagn Microbiol Infect Dis. 2007;57:295-9. https://doi. org/10.1016/j.diagmicrobio.2006.09.001 
25. García AL, Kindt A, Bermúdez H, Llanos A, De Doncker $\mathbf{S}$, Arévalo $\mathbf{J}$, et al. Culture-independent species typing of neotropical Leishmania for clinical validation of a PCRbased assay targeting heat shock protein 70 genes. J Clin Microbiol. 2004;42:2294-7. https://doi.org/10.1128/jcm.42. 5.2294-2297.2004

26. Ovalle C, Porras L, Rey M, Ríos M, Camargo Y. Distribución geográfica de especies de Leishmania aisladas de pacientes consultantes al Instituto Nacional de Dermatología Federico Lleras Acosta, E.S.E., 1995-2005. Biomédica. 2006:26:14551. https://doi.org/10.7705/biomedica.v26i1.1508

27. Urbano J, Sánchez M, Ovalle C, Rosales MJ, Camargo Y, Gutiérrez R, et al. Characterization of cutaneous isolates of Leishmania in Colombia by isoenzyme typing and kDNA restriction analysis. Revista lbero-latinoamericana de Parasitología. 2011;70:16-24.

28. Ovalle C, Díaz Y, Muvdi S. Polymerase chain reactionminiexon: A promising diagnostic method for mucosal leishmaniasis. Int J Dermatol. 2015;57:295-9. https://doi. org/10.1111/ijd.12910

29. Cruz ML, Ovalle C, Ortegón V, Pérez JE, Echeverry MC. Improving Leishmania species identification in different types of samples from cutaneous lesions. J Clin Microbiol. 2015;53:1339-41. https://doi.org/10.1128/jcm.02955-14

30. Serin MS, Daglioglu K, Bagirova M, Allahverdiyev A, Uzun S, Vural Z, et al. Rapid diagnosis and genotyping of Leishmania isolates from cutaneous and visceral leishmaniasis by microcapillary cultivation and polymerase chain reaction-restriction fragment length polymorphism of miniexon region. Diagn Microbiol Infect Dis. 2005;53:20914. https://doi.org/10.1016/j.diagmicrobio.2005.05.007

31. Montalvo AM, Fraga J, Goodridge IM, Fidalgo LM, Marín M, van Der Auwera G, et al. Differentiation of Leishmania (Viannia) panamensis and Leishmania (V.) guyanensis using Bccl for hsp70 PCR-RFLP. Trans R Soc Trop Med Hyg. 2010;104:364-7. https://doi.org/10.1016/j. trstmh.2009.12.002

32. Montalvo AM, Fraga J, Monzote L, Montaño I, De Doncker S, Dujardin JC, et al. Heat-shock protein 70 PCR-RFLP: A universal simple tool for Leishmania species discrimination in the New and Old World. Parasitology. 2010;137:1159-68. https://doi.org/10.1017/s0031182010000089

33. Walton BC, Shaw JJ, Lainson R. Observations on the in vitro cultivation of Leishmania braziliensis. J Parasitol. 1977;63:1118-9. https://doi.org/10.2307/3279862

34. Saravia N, Holguín AF, McMahon-Pratt D, D'Alessandro A. Mucosal leishmaniasis in Colombia: Leishmania braziliensis subspecies diversity. Am J Trop Med Hyg. 1985;34:714-20. https://doi.org/10.4269/ajtmh.1985.34.714

35. Saravia N, Segura I, Holguín AF, Santrich C, Valderrama L, Ocampo C. Epidemiologic, genetic, and clinical associations among phenotypically distinct populations of Leishmania (Viannia) in Colombia. Am J Trop Med Hyg. 1998;59:86-94. https://doi.org/10.4269/ajtmh.1998.59.86

36. Godfrey D, Kilgour V. Enzyme electrophoresis in characterizing the causative organism of Gambian trypanosomiasis. Trans R Soc Trop Med Hyg. 1976;70:219-24. https://doi. org/10.1016/0035-9203(76)90043-2
37. Wagner DB, Furnier GR, Saghai-Maroof MA, Williams SM, Dancik BP, Allard RW. Chloroplast DNA polymorphisms in lodgepole and jack pines and their hybrids. Proc Natl Acad Sci USA. 1987;84:2097-100. https://doi. org/10.1073/pnas.84.7.2097

38. García AL, Parrado R, De Doncker S, Bermúdez H, Dujardin JC. American tegumentary leishmaniasis: Direct species identification of Leishmania in non-invasive clinical samples. Trans R Soc Trop Med Hyg. 2007;101:368-71. https://doi.org/10.1016/j.trstmh.2006.06.009

39. Landis JR, Koch GG. The measurement of observer agreement for categorical data. Biometrics. 1977;33:15974. https://doi.org/10.2307/2529310

40. Andrews R, Chilton N. Multilocus enzyme electrophoresis: A valuable technique for providing answers to problems in parasite systematics. Int J Parasitol. 1999;29:213-53. https://doi.org/10.1016/S0020-7519(98)00168-4

41. Tsokana CN, Athanasiou LV, Valiakos G, Spyrou V, Manolakou K, Billinis C. Molecular diagnosis of leishmaniasis, species identification and phylogenetic analysis. In: Claborn DM, editor. Leishmaniasis - Trends in epidemiology, diagnosis and treatment. Croatia: InTech; 2014. p. 61-193. https://doi.org/10.5772/57067

42. van der Auwera G, Dujardin JC. Species typing in dermal leishmaniasis. Clin Microbiol Rev. 2015;28:265-94. https:// doi.org/10.1128/cmr.00104-14

43. van der Auwera G, Ravel C, Verweij JJ, Bart A, Schonian G, Felger I. Evaluation of four single-locus markers for Leishmania species discrimination by sequencing. J Clin Microbiol. 2014;52:1098-104. https://doi.org/10.1128/jcm. 02936-13

44. Saki J, Meamar A, Oormazdi H, Akhlaghi L, Maraghi S, Mohebali M, et al. Mini-exon genotyping of Leishmania species in khuzestan province, southwest Iran. Iran J Parasitol. 2010;5:25-34.

45. Montalvo AM, Fraga J, Maes I, Dujardin JC, van der Auwera G. Three new sensitive and specific heat-shock protein 70 PCRs for global Leishmania species identification. Eur J Clin Microbiol Infect Dis. 2012;31:1453-61. https://doi.org/10.1007/s10096-011-1463-z

46. Fraga JA, Montalvo M, van der Auwera G, Maes I, Dujardin JC, Requena JM. Evolution and species discrimination according to the Leishmania heat-shock protein 20 gene. Infect Genet Evol. 2013;18:229-37. https://doi. org/10.1016/j.meegid.2013.05.020

47. van der Auwera G, Maes I, De Doncker S, Ravel C, Cnops L, van Esbroeck M, et al. Heat-shock protein 70 gene sequencing for Leishmania species typing in European tropical infectious disease clinics. Euro Surveill. 2013;18:19. https://doi.org/10.2807/1560-7917.es2013.18.30.20543

48. Montalvo AM, Fraga J, El Safi S, Gramiccia M, Jaffe CL, Dujardin JC, et al. Direct Leishmania species typing in Old World clinical samples: Evaluation of 3 sensitive methods based on the heat-shock protein 70 gene. Diagn Microbiol Infect Dis. 2014;80:35-9. https://doi.org/10.1016/j. diagmicrobio.2014.05.012

49. Rodríguez I, Góngora R, Prager M, Pacheco R, Montero LM, Navas A, et al. Etiologic agent of an epidemic of cutaneous leishmaniasis in Tolima, Colombia. Am J Trop Med Hyg. 2008;78:276-82. 
50. Fernández OL, Díaz Y, Ovalle C, Valderrama L, Muvdi S, Rodríguez I, et al. Miltefosine and antimonial drug susceptibility of Leishmania Viannia species and populations in regions of high transmission in Colombia. PLoS Negl Trop Dis. 2014;8:1-11. https://doi.org/10.1371/journal. pntd. 0002871

51. da Silva LA, dos Santos de Sousa C, da Graça GC, Porrozzi R, Cupolillo E. Sequence analysis and PCRRFLP profiling of the hsp70 gene as a valuable tool for identifying Leishmania species associated with human leishmaniasis in Brazil. Infect Genet Evol. 2010;10:77-83. https://doi.org/10.1016/j.meegid.2009.11.001

52. Hernández C, Álvarez C, González C, Ayala MS, León CM, Ramírez JD. Identification of Six New World Leishmania species through the implementation of a High-Resolution Melting (HRM) genotyping assay. Parasit Vectors. 2014;7:17. https://doi.org/10.1186/preaccept-1870264614134473

53. Cardoso G, Volpini AG, Sierra GA, Paes M, Hueb M, Porrozzi $\mathbf{R}$, et al. Development and validation of PCRbased assays for diagnosis of American cutaneous leishmaniasis and identification of the parasite species. Mem Inst Oswaldo Cruz. 2012;107:664-74. https://doi.org/10.1590/ s0074-02762012000500014

54. Camara LI, Paes M, Guerra JA, das Graças M, Coelho C, Lima B, et al. Characterization of Leishmania spp. causing cutaneous leishmaniasis in Manaus, Amazonas, Brazil. Parasitol Res. 2011;108:671-7. https://doi.org/10.1007/ s00436-010-2139-9 